\title{
The Constitutional Accountability for Open Standards
}

\author{
Felix Greve ${ }^{a}$ \\ (a) German Lawyer
}

DOI: 10.5033/ifosslr.v8i1.110

\begin{abstract}
This article summarises a doctoral dissertation at the Faculty of Law at the University of Hamburg, Germany. The thesis has been published 2015 as part of a publication series of the Hans-Bredow-Institut, Hamburg, with NOMOS Publishing House, Baden-Baden.

The dissertation herein summarised provides a concrete legal substantiation of an accountability of the State to enact a regulatory framework which ensures vendor-independent data formats in the private market (below chapter VI-VII). As a result, this work offers the necessary objective, perspective, regulatory means and the avoidance of complex evidential problems to legally ensure interoperability in the market of telematics. In order to derive these results the economic, social and technical background as well as the actual existing influence possibilities of the State must be outlined first (chapter I-V).

Although the findings summarised here are primarily derived from German law, they are likely to be applicable to other European legislations as well due to the fact that German telecommunication law is considerably superimposed by European telecommunication law.
\end{abstract}

\section{Keywords}

Open Standards, Telecommunication Law, E-Government; Competition Law, Regulation, File Formats, Free Software

\section{Definition of Problem}

The transformation of a production-oriented industrial society into a knowledge-based information society already began during the 1960s. As a result, the social significance of knowledge and information has grown exponentially ever since ${ }^{1}$. On the technical side of transmission and archiving of information, digital systems have replaced traditional analog technologies.

This digitalisation of information technology is the most significant development in modern

1 Cf. Meier, Andreas: E-Democracy \& E-Government: Entwicklungsstufen einer demokratischen Wissensgesellschaft, Berlin, Heidelberg: 2009, p. 3. 
telecommunication and leads to a radical culture change ${ }^{2}$. The related upheavals result in impacts that are comparable to the industrial revolution ${ }^{3}$, the invention of letterpress printing or even the introduction of written language ${ }^{4}$. The potential of digitisation by far exceeds the relevance of telegraph networks or modern voice telephony. In comparison with traditional analog means of communication, a new range and quality of services is accomplished by using digital technologies ${ }^{5}$. In particular, the convergence of classical and new services is made possible, such as film and television, written, voice, visual and other data communication. Through digital technology methods of communication that were previously separated are now converging into an all-encompassing interconnected system. By means of data transmission, individual written or verbal communication is just as realisable as a general distribution of texts, radio broadcasts or television. The boundaries between traditionally separated and new distribution paths are vanishing and the proceeding digitalisation allows that, for instance, services provided by telephone, radio, television sets or computers may no longer be rendered by separated mono-functional end-user equipment but instead by software-based multifunctional devices ${ }^{6}$.

Older communication media used analog technologies for fixation, archiving and transmission of information. In this context the term 'analog' describes the fact that, although the different stages of transmission of information differ in some respects, they are subject to the same basic principles. For example, an analog written paper form or image recording captures the information in a directly perceivable way ${ }^{7}$. In case of an analog transmission of information, for example, an analog radio broadcast or telephone call, the audible sound waves and the electro-magnetic waves used for long distance transmission behave analogously to each other. While converting the sound waves into electro-magnetic waves, the basic nature of the signal does not change. This is why the process of analog fixation and transmission of information is comprehensible in itself.

In contrast to previously commonly used direct analog fixation and transmission, modern digital technology is distinguished by an abstract and indirect encoding / transmission of information, by the way of interpreting two signal statuses ${ }^{8}$. When using digital technology, any messages (for example graphic characters, speech or pictures) are recorded in an analog form only as a first step. Subsequently the message must be binary-encoded, thus fragmented into two signal states according to defined abstract principles 9 . The circuits that computer technology depend on are only able to provide two signal states - electricity on and off $(0 \text { and } 1)^{10}$. The complex rules and principles which

2 European Commission, Green Paper on the Convergence of the Telecommunications, Media and Information Technology Sectors and the Implications for Regulation, December 02, 1997, p. ii, http://ec.europa.eu/archives/information society/avpolicy/docs/library/legal/com/greenp 97623 en.pdf.

3 Cf. European Commission, Green Paper on Convergence, ibid., p. 10; Grewlich, Klaus: Wettstreit im Regulierungsrecht der Kommunikation - Auswirkungen auf Unternehmen und Geschäftsallianzen, Kommunikation \& Recht 1998, p. 523530 , p. 623 et seq..

4 Coy/Tholen, HyperKult: Geschichte, Theorie und Kontext digitaler Medien, in Brunnstein, Klaus / Oberquelle, Horst: 25 Jahre Informatik an der Universität Hamburg: Informatik: Stand, Trends, Visionen - Festkolloquium 25 Jahre Informatik an der Universität Hamburg, Hamburg: 1997, p. 81.

5 Sommer, Stephan: Staatliche Gewährleistung im Verkehrs-, Post- und Telekommunikationsbereich: zur Interpretation der Gewährleistungsnormen der Art. 87e IV und 87f I GG im System verfassungsrechtlicher Leistungspflichten, Berlin: 2000, p. 12.

6 Paschke, Marian: Medienrecht, 3rd edition, Berlin: 2009, p. 6 et seq..

7 Cf. Wolfgang Coy: Digitale Kultur - Von alten und neuen Medien, Forum Kultur im Stadthaus Ulm, Ulm, lecture on February 25, 2000, p. 4, http://waste.informatik.hu-berlin.de/Coy/Papers/Coy Ulm 000225.pdf.

8 Cf. Fuchs, Klaus / Landgraf, Bernd: Informationsverarbeitung in der öffentlichen Verwaltung: Verwaltungsinformatik, 3rd edition, Bonn 1992, p. 13 and p. 18; Stallings, William: Data and Computer Communications, 6th edition, New Jersey: 2000, p. 132.

9 Jungheim, Stephanie: Medienordnung und Wettbewerbsrecht im Zeitalter der Digitalisierung und Globalisierung, Tübingen: 2012, p. 5.

10 Fuchs, Klaus / Landgraf, Bernd: Informationsverarbeitung in der öffentlichen Verwaltung: Verwaltungsinformatik, 3rd edition, Bonn 1992, p. 19; Stallings, William: Data and Computer Communications, 6th edition, New Jersey: 2000 , p. 32. 
are necessary for such an abstract encoding of information are defined by the data format used. Like compiled software code, such data formats are abstract artificial languages that must be specified by completely formal grammar and cannot be defined by their usage or context ${ }^{11}$.

In the course of information transfer, standards of digital message encoding hold a key position. Subsequent to the necessary step of digital encoding, only those recipients will have access to digitalised information who are actually able to implement the used data format. If communication is realised by maximum integration of vendor specific encoding of information, the information flow is consequently limited to vendor specific software. Whoever controls the technology in which information is encoded, controls the access to communication and is able to determine the modalities for utilisation ${ }^{12}$. This particularly applies to aspects of transparency and security, which has lately been demonstrated in the context of the revelations of Edward Snowden regarding NSA.

When a technical specification exclusively offered by a single supplier has penetrated the market without any interoperable implementations on offer from a competitor, it is misleadingly spoken of as a "proprietary standard"13. The establishment of a proprietary standard presupposes that the principles of a data format are kept secret and/or are protected as intangible property, and hence are not, or not completely, available to competitors and society. Strictly speaking, such proprietary standards are no standards at all, at least not in the proper sense of the word, but rather the de-facto usual that is vendor specific ${ }^{14}$.

Examples of lacking compatibility in the course of digital information encoding are numerous and diverse. For instance, during the catastrophic flood in Southeast Asia in 2004 it was not possible to exchange documents necessary for rescue and identification of victims among governmental agencies due to vendor specific document formats ${ }^{15}$. The vendor specific encoding of FEMA aid online, the official governmental website for coordination of disaster relief in the USA, prevented some victims of Hurricane Katrina from registering; at first only victims using Microsoft Internet Explorer where able to sign up for governmental assistance and support ${ }^{16}$. Also the Live-Stream of the European Parliament available on the Internet had until recently been encoded in a vendor-specific manner and only individuals using the Windows Media Player were able to view the stream ${ }^{17}$.

In order to allow communication, a technical process must be organised and unified. Unlike a nongrid-bound energy supply with mineral oil and coal, the communication infrastructure is a synchronised and cooperative machine ${ }^{18}$. Thus, for decades the telephone system was called the "biggest machine of the world" 19 . What makes a network system into a consistent machine is the successful cooperation of its individual parts. Within the modern and privatised telecommunication market, the necessary technical standardisation does not only determine the communication channels

11 Coy, Die Sprache(n) des Internets, in Panagl, Oswald / Goebl, Hans / Brix, Emil: Der Mensch und seine Sprache(n), Weimar: 2001, p. 2.

12 Cf. Recke, Martin: Medienpolitik im digitalen Zeitalter: zur Regulierung der Medien und der Telekommunikation in Deutschland, Berlin: 1998, p. 39 et seq..

13 Greve, Felix: Die staatliche Gewährleistungsverantwortung für offene Standards, Baden-Baden: 2015, p. 66 et seq..

14 Greve: ibid.

15 Cf. Berkman Center for Internet Society, Open ePolicy Group's Roadmap for Open ICT Ecosystems (September 2005), http://cyber.law.harvard.edu/epolicy/roadmap.pdf.

16 DeNardis / Eric Tam: Open Documents and Democracy, Yale Information Society Project, 2007; http://ssrn.com/abstract=1028073.

17 As at September 1, 2009, http://www.europarl.europa.eu/wps-europarl-internet/faces/live/live-video.jsp?language=de.

18 Cf. Schivelbusch, Wolfgang: Lichtblicke: zur Geschichte der künstlichen Helligkeit im 19. Jahrhundert, Frankfurt am Main: 2004, p. 34.

19 Cf. Recke, Martin: Medienpolitik im digitalen Zeitalter: zur Regulierung der Medien und der Telekommunikation in Deutschland, Berlin: 1998, p. 24. 
between the individual users but it also determines whether or not competitors might have effective opportunities of accessing the market.

Nowadays, digital telecommunication not only creates the prerequisite for changed economic structures, but also for modern political systems ${ }^{20}$. The convergent process of digital transmission of information constitutes a key element of democratic, social and economic processes and thus is of considerable importance. Convergent transmission of digital information, its services and applications have an impact on every aspect of our lives: our home, our workplace, our access to healthcare, the economy, public services and different forms of participation in a democratic society ${ }^{21}$.

Such a key function already made the telegraph network, and later the telephone network, into evident and undeniable objects of State interest. The same applies to the modern, digital and convergent system of telecommunication. Consequently, governments and political leaders bear a special responsibility for this fundamental infrastructure ${ }^{22}$. The values underlying this responsibility of the State are reflected in the German constitution ${ }^{23}$, are to be found in several aspects of European Community law and are globally recognised as well ${ }^{24}$. In accordance with provisions of European law, the German federal legislator in article $87 \mathrm{f}$ GG (German constitution) has a statutory duty to regulate the telecommunication sector ${ }^{25}$. Besides that, article $5 \mathrm{GG}^{26}$ already sets out the Federal Republic of Germany as being a free information society. Same basic principles apply in EU law and in other member states as well ${ }^{27}$. Free information flow must be open for participation, thereby ensuring that nobody is excluded from the outset ${ }^{28}$.

It is therefore not a mere technical question in which data format information is saved and exchanged, but rather a decision with great economic and social significance ${ }^{29}$. Consequently, the problems of vendor-specific proprietary standards for digital information encoding have been discussed for quite some time in political and expert circles worldwide. However, only sector-specific

20 Cf. Latzer, Michael: Mediamatik: die Konvergenz von Telekommunikation, Computer und Rundfunk, Opladen: 1997, p. 15.

21 Cf. European Commission, Green Paper on the Convergence of the Telecommunications, Media and Information Technology Sectors, and the Implications for Regulation, December 02, 1997, p. 10, http://ec.europa.eu/archives/information society/avpolicy/docs/library/legal/com/greenp 97623 en.pdf; recital (2)-(5) of the Directive 2003/98/EC of the European Parliament and of the Council of 17 November 2003 on the re-use of public sector information, amended by Directive 2013/37/EU.

22 European Commission, Green Paper on Convergence, ibid., p. iii.

23 Cf. Frühmorgen, Michael: Daseinsvorsorge und Wettbewerb im Telekommunikationsrecht: eine Untersuchung zu Kontinuität und Wandel staatlicher Verantwortung für Telekommunikation unter besonderer Berücksichtigung der TKGNovelle 2004, Hamburg: 2007, p. 83 et seq..

24 Cf. Communication from the European Commission: Services of General Interest in Europe, KOM 2000, p. 580; Eumann, Marc: Organisationsrechtliche Probleme kommunaler Daseinsvorsorge in den Vereinigten Staaten von Amerika, Berlin: 1999, p. 47; Säcker, Franz Jürgen: Das Regulierungsrecht im Spannungsfeld von öffentlichem und privatem Recht: Zur Reform des deutschen Energie- und Telekommunikationsrechts, Archiv des öffentlichen Rechts 2005, p. 180-224, p. 180 (191).

25 Greve, Felix: Die staatliche Gewährleistungsverantwortung für offene Standards, Baden-Baden: 2015, p. 253 et seq..

26 Constitutional right to freedom of expression and information.

27 Cf. Piana, Carlo / Öberg, Ulf: Ensuring utmost transparency - Free Software and Open Standards under the Rules of Procedure of the European Parliament, International Free and Open Software Law Review, p. 11 et seq..

28 Kloepfer, Verfassungsrechtliche Grundlagen des Zugangs zu Medien- und Telekommunikationseinrichtungen, in Prütting, Hanns: Probleme des Zugangs zu den Medien und Telekommunikationseinrichtungen sowie Fragen der Zugangssicherung: Vortragsveranstaltung des Instituts für Rundfunkrecht an der Universität zu Köln vom 9. Mai 2003, München: 2003, Chapter A, I, p. 1; cf. Jungheim, Stephanie: Medienordnung und Wettbewerbsrecht im Zeitalter der Digitalisierung und Globalisierung, Tübingen: 2012, p. 35.

29 Cf. Auswärtiges Amt / Bundesministerium für Wirtschaft und Technologie / Bundesministerium des Innern / Bundesarchiv / Bundesbeauftragter für den Datenschutz und die Informationsfreiheit / Bundesamt für Sicherheit in der Informationstechnik, Initiativpapier - Offene Dokumentenaustauschformate für die Bundesverwaltung, p. 1, http://www.cio.bund.de/SharedDocs/Publikationen/DE/Architekturen-und-Standards/initiativpapier de download.pdf? blob=publicationFile. 
analyses have been conducted and the present topic has not been analysed in the necessary overall context. Accordingly, quite different approaches have been discussed. Where vendor-specific technologies have already been established in the market in general, the applied means to solve such interoperability problems have failed so far due to a limited perspective, the lack of regulatory procedures and ultimately the prevailing market reality.

In the course of current statutory provisions and underlying conceptual ideas that have been adapted to cover mono-functional and analog technical capabilities, the changed technical processes and potentials of digital transmission of information lead to difficulties of application and interpretation of law. Inconsistencies and significant need for clarification arise especially in relation to telecommunication, media, intellectual property and competition law, as well as the so called egovernment.

\section{The Relevance of Technical Standards}

It is of utmost importance to understand the role of technical standards in the process of digital telecommunication ${ }^{30}$. Technical standards do not constitute legal rules. Usually they are compiled by non-governmental private associations or individual commercial enterprises that are neither institutionally integrated as public administration nor act as public authority. It is only in particular cases that legal rules make reference to individual technical standards so that a legal binding effect is generated. However, within the framework of transmission of digital messages, market realities and technical dependencies constitute de facto binding effects which are quite comparable to legal norms.

Complex network effects and a very effective vendor lock-in lead to a situation where only one specification for encoding of information can prevail irrespective of whether it is a vendor-specific or a vendor-neutral standard. But the degree of vendor independence / openness of the prevailing standard determines how vendor-independent, open and functional the process of digital communication is organised and whether reliable long-term archiving is possible.

Only joint and vendor-independent standards are able to provide effective possibilities of market access and bear sufficient assurance that long-term archiving will be achievable ${ }^{31}$. In contrast, under an established vendor-specific standard, competition is prevented ${ }^{32}$, telecommunication capabilities are bound to an individual vendor ${ }^{33}$, future presentation of archived information is endangered ${ }^{34}$ and the effect of convergence is limited to the field in which the vendor who owns the proprietary standard is developing solutions ${ }^{35}$. Joint technical standards can therefore be desirable or threatening, depending on whose interests are being pursued ${ }^{36}$.

Common vendor-independent standards may be formal standards, de jure standards or de facto standards. Only such joint standards at the level of encoding of digital messages will enable competition within an interconnected telecommunication market ${ }^{37}$. This applies on the one hand to competition in the software market, which depends on a particular standard technology, and on the

30 Cf. Aliprandi, Simone, Interoperability And Open Standards: The Key To True Openness And Innovation, International Free and Open Source Software Law Review, Vol. 3, No. 1, pp. 5-24, p. 5 et seq..

31 Greve, Felix: Die staatliche Gewährleistungsverantwortung für offene Standards, Baden-Baden: 2015, p. 41 et seq..

32 Greve: ibid., p. 45 et seq. and p. 49 et seq..

33 Greve: ibid., p. 31 et seq..

34 Greve: ibid., p. 41 et seq..

35 Greve: ibid., p. 38 et seq..

36 Updegrove, Standards Wars: Situations, Strategies, and Outcomes, in Bolin, Sherrie: Unifier or Divider?, The Standards Edge, The Bolin Group conference analysis, forthcoming, printed by Sherdian Books, p. 34. 
other hand to competition among different standard technologies, which only by their interchangeability can compete on the basis of quality and not distribution.

In contrast, vendor-specific data formats put through by a market leader or monopolist are incompatible with software solutions of other vendors. Such proprietary standards hold their ground in the market quite independently of the software and the data format quality because only the combination between market-leading proprietary software and market-dominating vendor-specific data format enables information processing and communication.

As a counter-term to proprietary standards, so-called open standards ${ }^{38}$ are demanded mostly in the field of digital encoding of messages. The extent to which the standards should be open and vendor independent in order to constitute such open standards is highly controversial. Therefore, to what extent competitors may implement open standards in a manner that is vendor-independent as well as transparent is to a large degree determined by which definition is applied and which interest group is making reference to an 'open standard'.

\section{Inconsistencies of Current Telecommunication Regulation}

Pursuant to European legal guidelines, the purpose of German telecommunication law is to enable effective market access opportunities in all areas of telecommunication and, additionally, to implement concrete political objectives related to public welfare into the privatised telecommunication market. Classical methods to achieve these goals are product-related regulatory instruments, such as technical standardisation.

Despite the fact that data formats are a mandatory part of any transmission of digital information, this aspect is currently largely ignored in telecommunication regulation as well as in jurisprudential discussion $^{39}$. Whilst German telecommunication law has established a close supervision and regulation of technical standardisation between network-and-terminal-devices, as well as between network-and-network, the interoperability of terminal devices among each other (in particular the encoding of the information contained in the transmitted binary code) plays no more than a very subordinate role ${ }^{40}$.

In large part this is due to the fact that the focus of attention traditionally lies on classical fixednetwork voice telephony (by now digitalised) which presently requires no regulation at all. In this area there is currently no risk of monopolising the principles for the encoding of messages. The process of digital encoding, which is so central for the interoperability of terminal devices, is conducted in accordance with principles of a vendor-independent and royalty-free standard published

37 Cf. FLOSSPOLS (2005) Open Standards and Interoperability Report: An Economic Basis for Open Standards, Deliverable D4, MERIT, University of Maastricht, flosspols.org, p. 5 et. seq..

38 Cf. Piana, Carlo / Öberg, Ulf: Ensuring utmost transparency - Free Software and Open Standards under the Rules of Procedure of the European Parliament, International Free and Open Software Law Review, p. 32 et seq.; Dolmans, Maurits / Piana, Carlo: A Tale of Two Tragedies - A plea for open standards, p. 122 et seq.; Gandal, An Introduction to the Economics Literature on Standards Setting Organizations, in Bolin, Sherrie: The Standards Edge, Unifier or Divider?, The Bolin Group conference analysis, forthcoming, printed by Sherdian Books, p. 110; Rosen, Defining Open Standards, in Bolin: The Standards Edge, Unifier or Divider?, S. 170; Spring/Oksala, Creating Better Standards More Efficiently, in Bolin: The Standards Edge, Unifier or Divider?, p. 207; Walli, Standards and Open Source Software: Market UnifierExcept When They're Not, in Bolin: The Standards Edge, Unifier or Divider?, p. 79.

39 Greve, Felix: Die staatliche Gewährleistungsverantwortung für offene Standards, Baden-Baden: 2015, p. 215 et seq.; cf. Heise, Michael: Das Verhältnis von Regulierung und Kartellrecht im Bereich der Netzwirtschaften, Zur Frage der Herausbildung eines eigenständigen Netzwirtschaftsrecht, Berlin: 2008, p. 41.

40 Cf. Koenig, Christian / Loetz, Sascha / Neumann, Andreas: Telekommunikationsrecht, Heidelberg: 2004, p. 35. 
by the International Telecommunication Union, namely the G.711-Codec ${ }^{41}$. Consequently, there is currently only a need to regulate the communication interfaces between the telephone and the electronic communication network in order to protect the terminal devices market against the market dominance of the formerly state-owned network monopolist.

In some other areas of modern telecommunication, technical standards for encoding of information that currently indisputably deserve the title 'open standard' have prevailed. For example, HTML for webpages and certain versions of the PDF standard for non-editable electronic documents. These market results are in accordance with the concept which has been the basis of privatisation of former state-owned telecommunication monopolies ${ }^{42}$.

At present, data formats are regulated as part of the telecommunication infrastructure only in the exceptional case of digital television sets with a 'classic' shape that offer the respective reception of 'classic' television. When vendor specific encoding of information threatened to monopolise the market, governmental regulation introduced joint and vendor-independent standards for data formats, cryptographic methods and even programming interfaces (API) into the private market before monopolisation could take place, i.e. vendor specific standards could be established ${ }^{43}$. The respective regulatory regime is required by European guidelines ${ }^{44}$ and implemented by German telecommunication law in paragraphs 48 et seq. TKG (German Telecommunications Act).

For all other modern forms of communication, only the transmission of abstract binary code from network termination point to network termination point is ensured by regulatory means. This applies even though vendor specific technologies have for decades successfully penetrated the terminal device software market. Governmental regulatory means in place only assure that any user may connect any terminal device to electronic communication networks. However, the fact that the reproduction of information content is only possible when a specific software solution is used is not at all addressed.

It would therefore appear that outside of the transmission of 'classic' television by means of 'conventional' networks, major barriers to interoperability have been established for decades without telecommunication regulation having been taken into account at all. As far as communication is facilitated by maximum integration of vendor-specific technologies, interoperable communication and hence competition is excluded in the affected market sector. Due to network effects and vendor lock-in, consumers will be bound to the adapted vendor-specific technology ${ }^{45}$. Accordingly, the main objective of telecommunication regulation in respect of terminal equipment remains unfulfilled, namely to enable consumers to use the terminal device of her/his choice for communication ${ }^{46}$.

This differentiation between telecommunication for the purpose of transmission of 'classic' television by means of 'conventional', but now digitised, television networks using terminal devices referred to

41 Greve, Felix: Die staatliche Gewährleistungsverantwortung für offene Standards, Baden-Baden: 2015, p. 392 et seq..

42 Möstl, in Maunz, Theodor / Herzog, Roman / Herdegen, Matthias: Grundgesetz Kommentar, Band VI, Loose-leaf 05.09.2013, Art. 87f Rn. 73.; Franzius, Claudio: Gewährleistung im Recht: Grundlagen eines europäischen Regelungsmodells öffentlicher Dienstleistungen, Tübingen: 2009, p. 44; Voßkuhle, Andreas: Beteiligung Privater an der Wahrnehmung öffentlicher Aufgaben und staatliche Verantwortung, Veröffentlichung der Vereinigung der Deutschen Staatsrechtslehrer 2003, p. 266 (312).

43 Greve: ibid., p. 223 et seq.

44 Cf. article. 2 lit. o) and article 18 of Directive 2002/21/EG (framework directive); annex VI of Directive 2002/22/EG (Universal Service Directive), amended by Directive 2009/136/EG.

45 Greve, Felix: Die staatliche Gewährleistungsverantwortung für offene Standards, Baden-Baden: 2015, p. 30 et seq. and p. 66 et seq.

46 Cf. recital (2) of Commission Directive 88/301/EEC of 16 May 1988 on competition in telecommunications terminal markets (the terminal Directive); recital (10) of Directive 2008/63/EG. 
as 'television sets' versus any other forms of modern telecommunication cannot be justified either technically or from a legal standpoint. There are no convincing arguments why only devices sold under the denomination 'digital television sets' and no other shape factors which are equally able to receive 'classic' television by means of 'conventional' networks should be covered by the regulatory regime of paragraphs 48 et. seq. TKG and the respective European guidelines ${ }^{47}$. Furthermore, there is no objective reason why other devices which receive 'classic' television via the Internet (IP-TV) are not treated as 'digital television sets' as well ${ }^{48}$. Just as it remains unclear why digital transmission of documents via public communication networks does not need to be protected against monopolisation. These differentiations can only be explained with outdated mental models which are suited to analog, mono-functional and technically separated means of communication and cannot be perpetuated in the age of convergence ${ }^{49}$.

These general consequences of convergence need to be separated from the question, what regulatory density may be necessary in an individual case. In this respect, differentiations might be required and appropriate. After all, the convergent telecommunication services have quite different characteristics and effects ${ }^{50}$.

\section{Limitations of Competition Law}

In view of the outlined current lack of legal telecommunication regulation in respect of existing barriers to interoperability, the question arises which control options are offered by competition law. After all, a proprietary standard ${ }^{51}$ is equivalent to a barrier to entry for other competitors. This applies both to the software markets depending on the standard technology, as well as to the competition for the best standard technology.

However, only under very particular circumstances, proprietary standards may lead to consequences of competition law in an individual case ex post ${ }^{52}$. Only in the event that certain facts are to be proven and under a high degree of discretion, certain case groups may lead to an individual retrospective revision of particular market results. This is, however, of very limited practical value in a highly dynamic market of telematics ${ }^{53}$.

It is a fact that a proprietary standard always means a barrier to entry for other competitors within a market sector, which has been monopolised by that particular proprietary technology. But it follows from the dynamic principles of competition, which have been applied as a basis for the competition law in force, that dominant positions, or even monopolies by themselves, cannot be restricted by control options of competition law. Hence, taken in isolation, a dominant position or even a

47 Greve, Felix: Die staatliche Gewährleistungsverantwortung für offene Standards, Baden-Baden: 2015, p. 231 et seq. .

48 Schmits, in Säcker, Franz Jürgen: Telekommunikationsgesetz Kommentar, 3rd edition, Frankfurt am Main: 2013 , § 48 Rn. 18; Holznagel, Bernd: Die TKG-Novelle 2010, Kommunikation \& Recht 2010, p. 761 (767); cf. Greve: ibid., p. 234 et seq..

49 Greve: ibid., p. 243 et seq.

50 Cf. Baier, Jan: Zulassungspflicht für Web-TV? Maßgebliche Kriterien im Lichte des Rundfunkbegriffs, Computer und Recht 2008, p. 769 (773); Potthast, Klaus-Peter: Medienrechtliche Einordnung neuer Angebote über neue Übertragungswege (z.B. IP-TV, Mobil-TV etc.), Zeitschrift für Urheber- und Medienrecht 2007, p. 443 (446); cf. Greve: ibid., p. 234 et seq., p. 240 et seq. and p. 333 et seq..

51 Regarding this term: Greve: ibid., p. 66 et seq..

52 Greve: ibid., p. 169 et seq.; cf. ECJ judgement of 09.11.1983, Slg. 1983, 3461 (Michelin); ECJ judgement of 05.10. 1988, Slg. 1988, 6211 (Volvo/Veng); ECJ judgement of 10.07.1990, Slg 1990, II-309 (Tetra Pak/Commission); ECJ judgement 06.04.1995, Slg. 1995, I-743 (Magill); ECJ judgement of 29.04.2004, Slg. 2004, I-5039 (IMS Health)ECJ judgement of 17.09.2007, T-201/04 (Microsoft/Commission).

53 Greve: ibid., p. 336 et seq. 
monopoly as well as a vendor-specific proprietary standard does not violate competition law at all ${ }^{54}$. Rather, from this viewpoint, the tendencies towards monopoly in the telematics sector associated with network effects, by themselves, must be seen as a process which cannot be intervened by competition law ${ }^{55}$. Especially in markets in which network effects are highly effective and only one technical standard may survive, an embittered struggle for the greatest possible market share is part of functioning competition for the market and does not lead per se to competition law concerns ${ }^{56}$. Considered by itself from the point of view of competition law, it is irrelevant whether a proprietary standard, de facto standard, formal standard or even an open standard prevails.

\section{Overstrained E-government}

Today, the issue of lacking common technical standards for digital encoding of messages and the question which requirements should be fulfilled by such common standards, are primarily discussed in connection with e-government initiatives. After all, e-government as a future model is subject to the prerequisite of an interoperable telecommunication infrastructure. In particular, without open standards for the digital encoding of messages, central challenges of e-government remain unresolvable $e^{57}$.

However, only the omission of regulation by telecommunication law has led to the current situation that interoperability of data formats is primarily discussed as a prerequisite of a functioning egovernment. Instead, in connection with the regulation of the technical telecommunication infrastructure, solution approaches are currently being discussed in the context of the type of content that is being transported by the telecommunication infrastructure. This leads to serious problems because a general vendor dependence in the telecommunication infrastructure cannot be efficiently solved by specifying technical standards for individual governmental services.

Information campaigns and political decisions on principles, both internationally and in Germany, advocate the use of open standards in e-government. Primarily this is substantiated by the factual positive effects caused by the use of vendor-independent standards. However, it has not been successful to derive this requirement from concrete legal grounds; instead the respective reasoning confines itself to a mere reference to the principle of democracy and freedom of $\operatorname{speech}^{58}$. In accordance with the current legal situation, the primary aim of a particular e-government service remains to reach as many communication partners as possible and to enable respective up- and downstream data processing ${ }^{59}$.

Moreover, e-government as a communication service can only have an indirect impact on the privatised market by selective procurement ${ }^{60}$. If, however, a software has established itself in the market, and this software exclusively supports vendor specific encoding error-free, only a fraction of the population may be reached by solutions from other software providers - even if these solutions use data formats which are indeed vendor independent and hence interoperable. Ultimately, a market leader, who has successfully established a proprietary standard, has no interest in implementing a 
vendor-independent standard in a fully interoperable manner ${ }^{61}$. Therefore, a significant influence on the market will probably not be exerted. Under such conditions an exclusive use of open standards may in fact lead to failure or at least to a reduced acceptance of the e-government service in question.

Nevertheless, there are several pilot projects and concrete decisions of the German administration, which use and advocate open standards despite established vendor-specific technologies ${ }^{62}$. Internationally there are also numerous migration attempts. However, governmental agencies are caught in a predicament: on the one hand open standards are essential prerequisites for e-government services and moreover are socially desirable. On the other hand the main goal of an e-government service is to reach as many citizens as possible ${ }^{63}$. As a result of this problematic situation, where there is a market dominating proprietary standard, as a general rule, governmental authorities exclusively support the proprietary standard and, at best, implement a dual solution, thereby supporting the use of the proprietary standard and, as an alternative, an open standard that has not been established in the market. But there are substantial concerns about the practicality and the prospect of success of such a dual strategy ${ }^{64}$. Another approach is simply attempting to avoid monopolised channels of telecommunication and thus circumventing the problem of vendor lock-in instead of solving it.

Ultimately, in contrast to the various stated intentions and decisions of principle in which open standards are demanded, concrete technical e-government services currently rather depend on vendor-specific proprietary standards established in the market. Instead of opposing private monopolisations, the State submits to an existing market failure.

\section{The Constitutional Obligation for Open Standards}

Given the current limitation of telecommunication law regulation, the limited perspective of competition law and the powerlessness of e-government initiatives, the further conclusions of the dissertation herein summarised are becoming highly relevant. Under a thorough analysis, it becomes apparent that an accountability of the federal legislator for open standards regarding digital encoding of information is an inevitable consequence of governmental obligations with respect to the telecommunication infrastructure stipulated in article $87 \mathrm{f}$ GG (German constitution) ${ }^{65}$. This accountability necessarily refers to the entire telecommunication market, including any innovations and modern technologies ${ }^{66}$.

Proprietary standards on the level of encoding of information deprive the privatisation of the telecommunication sector of justification. Only if effective opportunities of market access actually exist, it may be expected that the intended increase of efficiency and the allocation effects optimising the common good can take effect ${ }^{67}$. Therefore, the federal legislator is being obligated in article 87f Abs. 2 S. 1 GG to continuously guarantee effective opportunities of market access, in order to enable the envisaged effects of the private market. In the area of telematics, interoperability and opportunities of market access are synonymous with vendor independent standards ${ }^{68}$. In contrast, the establishment of a proprietary standard is synonymous with a structural barrier to entry which

61 Greve: ibid., p. 50 et seq..

62 Greve: ibid., p. 154 et seq..

63 Cf. Piana, Carlo / Öberg, Ulf: Ensuring utmost transparency - Free Software and Open Standards under the Rules of

Procedure of the European Parliament, International Free and Open Software Law Review, p. 30 et seq..

64 Greve: ibid., p. 155 et seq..

65 Greve: ibid., p. 311 et seq..

66 Greve: ibid., p. 285 et seq. and p. 311 et seq.. 
prevents competition.

Private economic competition in the telecommunications sector has been permitted only under the condition that effective opportunities of market access are created, as well as maintained, and competitors remain bound to a special social responsibility ${ }^{69}$. After implementation of a vendorspecific proprietary standard, it is not to be expected that such a monopolised private market sector will be better suited than a single state-owned public enterprise to enable the potential for innovation of digital technology. In consequence of an established proprietary standard, and hence under absence of competition, it is left to the sole discretion of the private monopolist how and to what extent the former state-run service of general interest is fulfilled. In contrast to a state-owned monopolist, a private monopolist is not bound by administrative guidelines, fundamental rights of the population, national objectives, let alone the common good. Therefore, in such a market situation, it must be assumed that the privatised market is even less efficient for determining and fulfilling the common good than the state-owned monopoly ever was.

The concept of privatisation does not primarily call for individual standards developed or stipulated by the government as far as a market failure is ascertained. Telecommunication regulations must take into account that the affected markets are to a high degree dependent on technical aspects affected by enormous, barely assessable developments ${ }^{70}$. In consequence, the federal legislator primarily needs to establish relevant mandatory requirements in the context of which private competitors may develop individual technical standards and solutions. Structural barriers to competition must be dissolved but market results should not be anticipated. In contrast to such regulation of market structure, egovernment services must elect particular technologies. This leads to major difficulties where a solution that does not dominate the market is chosen.

In the regulatory environment of digital television (paragraphs 48 et seq. TKG and the respective European legal guidelines), all competitors regardless of a dominating position are committed to implement technical standards in compliance with certain minimum requirements ${ }^{71}$. Thus, the government provides a legal framework which ensures effective opportunities of market access and moreover implements the ideas of state welfare that have been democratically determined. Within this regulated market structure, private subjects define the technical details by standardisation of individual specifications. However, it should be clarified that the governmental responsibility for open standards does not necessarily preclude vendor specific and exclusive technologies. Rather, individual companies might very well continue to implement their more or less vendor-specific technologies but, besides these, they must also implement an open standard completely and operationally.

The globalisation of the information technology sector does not make an European or national

67 Benz, in König, Klaus / Benz, Angelika: Privatisierung und staatliche Regulierung, Bahn, Post und Telekommunikation, Rundfunk, Baden-Baden: 1997, p. 294 and p. 338; Benz: Veränderung staatlicher Aufgabenwahrnehmung durch Privatisierung - das Beispiel Telekommunikation, in Gusy, Christoph: Privatisierung von Staatsaufgaben: Kriterien Grenzen - Folgen, Baden-Baden: 1998, p. 153; Broemel, Roland: Strategisches Verhalten in der Regulierung - zur Herausbildung eines Marktgewährleistungsrechts in den Netzwirtschaften, Tübingen: 2010, p. 145; Grande, Privatisierung und Regulierung aus politikwissenschaftlicher Sicht, in Gusy, Christoph: Privatisierung von Staatsaufgaben: Kriterien Grenzen - Folgen, Baden-Baden: 1998, p. 44; König: in idem, Privatisierung und staatliche Regulierung, p. 69-70; Potacs, Michael: Herstellung von Wettbewerb als Verwaltungsaufgabe, Veröffentlichung der Vereinigung der Deutschen Staatsrechtslehrer 69 (2010), p. 254 (260).

68 Greve, Felix: Die staatliche Gewährleistungsverantwortung für offene Standards, Baden-Baden: 2015, p. 22 et seq..

69 Möstl, in Maunz, Theordor / Herzog, Roman / Herdegen, Matthias: Grundgesetz Kommentar, Band IV: Art. 86-106b, München: loose-leaf-collection, 68. supplement 2013, Art. 87f Rn. 40; cf. Greve: ibid., p. 264 et seq., and p. 271 et seq..

70 Benz in König, Klaus / Benz, Angelika: Privatisierung und staatliche Regulierung, Bahn, Post und Telekommunikation, Rundfunk, Baden-Baden: 1997, p. 344.

71 Greve, Felix: Die staatliche Gewährleistungsverantwortung für offene Standards, Baden-Baden: 2015, p. 223 et seq.. 
process of standardisation superfluous. The slow adjustment of international structures to changed power relations in the telecommunication sector in fact leads to an increasing importance of regional standardisation $^{72}$. However, the consequence of international dimension is that worldwide processes of development and global interests must be taken into account ${ }^{73}$.

In the future, it will become more and more relevant that the governmental responsibility for vendorindependent standards not only refers to communication between person and person as well as person and machine, but also increasingly to communication between machine and machine.

\section{Consequences}

The German federal legislator is therefore obligated under article $87 \mathrm{f}$ GG to provide a regulatory framework which ensures vendor-independent data formats in the privatised market. To fulfil this accountability and thereby solve the problem of lacking interoperability, it is advisable to choose regulatory means provided by sector-specific and hence the most appropriate telecommunication $\operatorname{law}^{74}$. After all, this area of law has the objective to fulfil the governmental responsibility regarding the telecommunication sector in a privatised market. Therefore, adjusted regulatory instruments are provided to enable competition in a complex network economy and moreover to achieve certain politically intended public interests. Telecommunication law offers the necessary objective, perspective, regulatory means and the avoidance of complex evidential problems to ensure interoperability in the market of telematics.

The federal legislator within its margin of discretion may choose other means to fulfil its accountability instead of enacting telecommunication law. For example, it may choose to adapt the regulations of competition law and/or certain e-government initiatives ${ }^{75}$. The exact manner in which the legislator fulfils its constitutional mandate is largely left to its discretion. However, the measures taken and laws enacted must neither be counterproductive nor absolutely inadequate to achieve the protection objectives ${ }^{76}$. In particular, the federal legislator cannot continue to simply ignore its constitutional obligation, as it has been doing so far.

From the particular perspective of the constitutional obligation regarding the telecommunication sector, a special situation arises in respect of the general need for standardisation. In general, it is not the objective of technical standardisation to fulfil governmental accountability or necessarily to enable effective opportunities of market access, but it is rather about the sole technical, economical or even the more restricted point of view of competition law ${ }^{77}$. In the course of the constitutional accountability for the telecommunication sector, effective opportunities of market access must be enabled and particular interests of public welfare - which are to be defined in a democratic process need to be ensured.

The degree of openness or vendor independence of mandatory standards to be defined is of crucial

72 Schultheiß, Kerstin: Europäische Telekommunikationsstandardisierung, eine normative Betrachtung, Münster: 2004, p. 124.

73 Schultheiß: ibid..

74 Greve, Felix: Die staatliche Gewährleistungsverantwortung für offene Standards, Baden-Baden: 2015, p. 333 et seq..

75 Cf. Greve: ibid., p. 348 et seq..

76 Stern, Klaus: Postreform zwischen Privatisierung und Infrastrukturgewährleistung, Deutsches Verwaltungsblatt 1997, p. 309 (314); Voßkuhle, Andreas: Beteiligung Privater an der Wahrnehmung öffentlicher Aufgaben und staatliche Verantwortung, Veröffentlichungen der Vereinigung der Deutschen Staatsrechtslehrer 2003, p. 267 (298).

77 Greve, Felix: Die staatliche Gewährleistungsverantwortung für offene Standards, Baden-Baden: 2015, p. 169 et seq. and p. 276 et seq.. 
importance. An open standard may have equal or at least very similar effects as a vendor-specific proprietary standard, depending on the definition and technical design. Therefore, even a specification referred to as an open standard may exclude, restrict or distort effective opportunities of market access and interoperability. Depending on the definition, open standards advertised to solve lacking interoperability may in fact become the cause of the problem instead of the solution.

With respect to the telecommunication regulation of digital television in paragraphs 48 et seq. TKG, technical specifications are treated as open standards when they are licensed under so-called (F)RAND terms ${ }^{78}$. However, it may be reasonably arguable that in general (F)RAND terms are in compliance with the ex-post evaluation of competition law $^{79}$. From the special perspective of constitutional accountability for open standards it becomes obvious that (F)RAND terms are not suitable to provide the necessary ex-ante market structure regulation ${ }^{80}$. The minimum requirement of a (F)RAND license is neither able to guarantee certain public interests nor effective opportunities of market access for competitors. In particular, it needs to be taken into account that Free Software ${ }^{81}$ is excluded from implementing (F)RAND licensed standards due to the recurring licence fees per utilisation and area of application ${ }^{82}$.

Following a thorough analysis, the constitutional accountability for open standards in article $87 \mathrm{f} \mathrm{GG}$ requires at least a royalty-free form of licensing. Although, under a royalty-free license ${ }^{83}$ it remains undetermined as well, which particular licence conditions may be demanded in an individual case. Royalty-free does not mean that the licensing is free of charge or additional restrictions. But in contrast to (F)RAND terms, the clear exclusion of recurring royalties leads to a higher degree of legal certainty regarding the future potential for implementing a common standard. This thereby considerably reduces the legal uncertainty which arises in connection with the legality of individual license conditions ${ }^{84}$. Thus, for instance, under a royalty-free license, implementations of the specification and, therefore, opportunities of market access are permitted regardless of the individual software license or business model ${ }^{85}$. Under a respective political decision, there are good reasons to go even farther and demand licence terms comparable with Free Software licences for open standards ${ }^{86}$.

However, as long as the accountability for market structure regulation in favour of vendor independent standards is not recognised, all future visions of the digital age are threatened to fail. Without the implementation of open standards, no interoperable information transmission and, therefore, in particular, no e-government, no paperless office and no electronic legal transaction will be feasible to the extent that has been promised for decades with tiresome regularity.

78 Regarding this type of licence: Greve: ibid., p. 84 et seq..

79 Greve: ibid., p. 169 et seq.; cf. ECJ judgement of 17.09.2007, T-201/04; (Microsoft/Commission); ECJ judgement of

27.06.2012, T-167/08 (Microsoft/Commission); Landgericht (district court) Düsseldorf, 4b O 274/10.

80 Greve: ibid., p. 318 et seq. and p. 327 et seq..

81 Greve: ibid., p. 110 et seq.

82 Greve: ibid., p. 84 et seq..

83 Regarding this type of licence: Greve: ibid., p. 89 et seq..

84 Greve: ibid., p. 91.

85 Greve: ibid., p. 314 et seq..

86 Greve: ibid., p. 314 et seq.. 


\section{About the author}

Felix Greve is a German lawyer primarily specialised on the intersection of IT and law. Besides ITLaw he mainly focuses on topics related to commercial law in general. During the past five years he has worked as a company lawyer for a globally operating transport logistics organisation, which is located in Hamburg, Germany.

\section{Licence and Attribution}

This paper was published in the International Free and Open Source Software Law Review, Volume 8, Issue 1 (2016). It originally appeared online at http://www.ifosslr.org.

This article should be cited as follows:

Greve, Felix (2016) 'The Constitutional Accountability for Open Standards ', International Free and Open Source Software Law Review, 8(1), pp. 45 - 58 DOI: $10.5033 /$ ifosslr.v8i1.110

Copyright (C) 2016 Felix Greve

This article is licensed under a Creative Commons Attribution 4.0 CC-BY available at https://creativecommons.org/licenses/by/4.0/

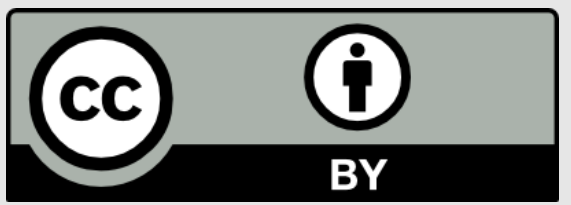

